\title{
Preparation, Characterization, and Biotoxicity of Nanosized Doped ZnO Photocatalyst
}

\author{
Lingling Liu, XiangRui Wang, Xiuping Yang, Wenhong Fan, \\ Xiaolong Wang, Ning Wang, Xiaomin Li, and Feng Xue \\ Key Laboratory of Bio-Inspired Smart Interfacial Science and Technology of Ministry of Education, Department of \\ Environmental Science and Engineering, School of Chemistry and Environment, Beihang University, Beijing 100191, China
}

Correspondence should be addressed to Wenhong Fan; fanwh@buaa.edu.cn

Received 4 April 2014; Accepted 29 April 2014; Published 22 May 2014

Academic Editor: Jiaguo Yu

Copyright (C) 2014 Lingling Liu et al. This is an open access article distributed under the Creative Commons Attribution License, which permits unrestricted use, distribution, and reproduction in any medium, provided the original work is properly cited.

\begin{abstract}
Metal-doped nanosized $\mathrm{ZnO}(\mathrm{nZnO})$ photocatalyst has been widely used for its typical properties and has thus gained considerable attention. In this study, five types of $\mathrm{nZnO}$ (nondoped $\mathrm{nZnO}$, iron- (Fe-) doped nZnO, cobalt- (Co-) doped nZnO, nickel- (Ni-) doped $\mathrm{nZnO}$, and manganese- ( $\mathrm{Mn}-)$ doped $\mathrm{nZnO}$ ) materials were prepared through a wet chemical method and then exposed to Daphnia magna (D. magna) at low and high concentrations $\left(50\right.$ and $250 \mu \mathrm{g} \mathrm{L}^{-1}$ ). Results showed that the different metal-doped nZnOs had a variety of shapes and sizes and exhibited diverse dissolubility. After exposure tests, $\mathrm{Zn}$ accumulation, metallothionein (MT), and malondialdehyde (MDA) contents in D. magna under $250 \mu \mathrm{g} \mathrm{L}^{-1}$ were significantly higher than those in the $50 \mu \mathrm{g} \mathrm{L}$ groups. Compared with nondoped $\mathrm{nZnO}$, Co-doped and Ni-doped $\mathrm{nZnO}$ enhanced $\mathrm{Zn}$ accumulation in D. magna whereas Mndoped $\mathrm{nZnO}$ reduced such accumulation. MT and MDA contents in metal-doped $\mathrm{nZnO}$ (except Ni-nZnO) treatments were lower than those in nondoped $\mathrm{nZnO}$. Zn accumulation showed a negative relationship with dissolved $\mathrm{Zn}$ percentage, which can be explained by the swallowing of $\mathrm{nZnO}$ particles as an important pathway of $D$. magna ingestion. Sizes, dissolubility, and physiological functions of doping metals were the influencing factors on metal-doped $\mathrm{nZnO}$ biotoxicity to $D$. magna.
\end{abstract}

\section{Introduction}

$\mathrm{ZnO}$ is an excellent photocatalyst because of its high electrical conductivity and optical transmittance in the solar spectrum. Particularly in a nanometer scale, nanosized $\mathrm{ZnO}(\mathrm{nZnO})$ exhibits numerous novel characteristics, such as high ratio of surface area to volume, high electron conductivity, and transmission capability, which provides more opportunities for potential applications in the areas of paint industry, biomedicine, and environmental engineering $[1,2]$.

However, the photocatalytic activity of $\mathrm{nZnO}$ is highly dependent on its crystallite size, specific surface area, morphologies, and UV irradiation wavelengths $[3,4]$. Numerous studies had proven that modified nZnOs with other elements improve photocatalytic properties. N-containing $\mathrm{ZnO}$ showed higher visible-light photocatalytic activity than pure $\mathrm{ZnO}$ [5]. ZnO-coated steel mesh has been repeatedly used for over 10 cycles without significant loss of catalyst mass [6]. The photocatalytic properties of the Co-doped $\mathrm{ZnO}$ had also been found to have improved significantly, and the degradation ratio of an organic dye (methyl orange) reached $78 \%$ when the doping concentration was 3\% [7]. Mndoped $\mathrm{ZnO}$ bleached methylene blue considerably faster than nondoped $\mathrm{ZnO}$ upon exposure to visible light [8].

Widespread use has caused these doped $\mathrm{nZnO}$ photocatalysts to enter the environment inevitably, thus resulting in intentional and unintentional exposures and giving rise to environmental and health risks [9]. $\mathrm{Zn}^{2+}$ ion dissolution, nanoscale size, and oxidative damage comprise the widely accepted potential mechanism of nZnO toxicity [10]. To the best of our knowledge, only the toxicity of Fe-doped $\mathrm{nZnO}$ was evaluated by Xia et al. [11], who revealed that Fe doping reduced $\mathrm{nZnO}$ dissolution, thus preventing its toxicity to animals and the environment. However, these findings are insufficient to facilitate understanding of the effect of doping on $\mathrm{nZnO}$ toxicity. 
In this study, we synthesized five doped $\mathrm{nZnO}$ photocatalysts (nondoped, Fe-doped, Co-doped, Ni-doped, and Mndoped) through a wet chemical method. The morphology and dissolubility of these photocatalysts in natural water were characterized. $\mathrm{Zn}$ accumulation, metallothionein, and lipid peroxidation contents of Daphnia magna (D. magna) in response to five $\mathrm{nZnO}$ exposures were quantified to evaluate the biotoxicity of $\mathrm{nZnO}$ photocatalysts. The influence and relationships of metal-doped $\mathrm{nZnO}$, as well as the toxic effects to D. magna, were analyzed and discussed. These results facilitated understanding of the effects of element doping on $\mathrm{nZnO}$ photocatalyst toxicity.

\section{Materials and Methods}

2.1. Preparation of Doped $n \mathrm{ZnO}$ Photocatalysts. The metaldoped $\mathrm{nZnO}(\mathrm{M}-\mathrm{nZnO})$ powders were obtained by using a wet chemical method in aqueous solutions as reported previously [12]. First, zinc nitrate hexahydrate $\left[\mathrm{Zn}\left(\mathrm{NO}_{3}\right)_{2} \cdot 6 \mathrm{H}_{2} \mathrm{O}\right]$ and hexamethylenetetramine $\left(\mathrm{C}_{6} \mathrm{H}_{12} \mathrm{~N}_{4}\right)$ with a certain concentration of $\mathrm{Fe}(\mathrm{Co}, \mathrm{Ni}$, and $\mathrm{Mn}$ ) nitrate hexahydrate were separately dissolved in $100 \mathrm{~mL}$ of deionized water. The concentrations of each metal dopant were 5\% in molarity. Subsequently, the mixture was placed into glass vials and heated at $95^{\circ} \mathrm{C}$ for several hours to grow metal-doped $\mathrm{nZnO}$. Thereafter, the containers were taken out and cooled naturally to room temperature. The samples were rinsed thoroughly with deionized water and dried at $100^{\circ} \mathrm{C}$ for $2 \mathrm{~h}$. Finally, metal-doped $\mathrm{nZnO}(\mathrm{Fe}, \mathrm{Co}, \mathrm{Ni}$, and $\mathrm{Mn}$ ) powders were obtained. The nondoped nZnO samples were synthesized through the same process without adding other metals.

2.2. Characterization of $n \mathrm{ZnO}$ Photocatalysts. The morphology of five types of $\mathrm{nZnO}$ (nondoped $\mathrm{nZnO}, \mathrm{Fe}-\mathrm{nZnO}, \mathrm{Co}-$ $\mathrm{nZnO}, \mathrm{Ni}-\mathrm{nZnO}$, and $\mathrm{Mn}-\mathrm{nZnO}$ ) particles in water was observed by using a JEOL transmission electron microscope (TEM) (JEOL, JEM-2100F), which was operated at $100 \mathrm{kV}$. The $\mathrm{nZnO}$ stocks were under ultrasonic treatment for better dispersion before making TEM samples. Several droplets of $\mathrm{nZnO}$ stock solution were injected into the Formvarcoated (Electron Microscopy Sciences, Fort Washington, PA, USA) copper grids using a capillary tube. After drying at room temperature, the samples were placed in the TEM for imaging.

The dissolubility of the five types of $\mathrm{nZnO}$ in natural water was investigated through dissolution tests. The $\mathrm{nZnOs}$ were dissolved in $\mathrm{pH} 8.5$ natural water contained in $100 \mathrm{~mL}$ Erlenmeyer flasks. The concentration of $\mathrm{nZnO}$ was $100 \mu \mathrm{g} \mathrm{L}^{-1}$. Three replicates were set up for each kind of $\mathrm{nZnO}$. After rapid mixing, the flasks were placed on a shaker at $150 \mathrm{rpm}$. Then, a $10 \mathrm{~mL}$ aliquot was removed at 30,60, 120, 180, and $240 \mathrm{~min}$. These samples were centrifuged at $12000 \mathrm{rpm}$ for 10 min with a versatile compact centrifuge (Himac CF 16RX, Hitachi, Tokyo, Japan) to separate $\mathrm{nZnO}$ particles. The $\mathrm{Zn}^{2+}$ concentration in the supernatant was determined by using inductively coupled plasma mass spectrometry (ICP-MS) and then used to calculate the quantity of dissolved $\mathrm{nZnO}$ in the water. The water that was used in both the dissolubility and toxicity experiments was collected near Huo Qi Ying Bridge $\left(116^{\circ} 16^{\prime} 732 \mathrm{E}, 39^{\circ} 58^{\prime} 401 \mathrm{~N}\right)$.

\subsection{Biotoxicity Test of Doped $n \mathrm{ZnO}$ Photocatalysts}

2.3.1. Toxicity Exposure of D. magna to $\mathrm{nZnO}$ Photocatalysts. The test organism was D. magna, an ecologically important freshwater zooplankton widely used in toxicity tests. $\mathrm{NZnO}$ stock suspension was prepared with natural water and dispersed evenly through ultrasonic treatment. $\mathrm{NZnO}$ concentrations of stocks were determined according to the metal concentrations of $\mathrm{Zn}, \mathrm{Fe}, \mathrm{Co}, \mathrm{Ni}$, and $\mathrm{Mn}$ in the suspension by utilizing inductively coupled plasma atomic emission spectrometry (ICP-AES). The suspension was then diluted with natural water, and two treatment concentrations (50 and $250 \mu \mathrm{g} \mathrm{L}^{-1}$ ) of each $\mathrm{nZnO}$ were used in the experiments. The natural water sample without $\mathrm{nZnO}$ was used as the control. Two replicates were set up for each treatment, each containing 50 daphnids ( 1 individual/10 mL) aged $14 \mathrm{~d}$ to $21 \mathrm{~d}$. The daphnids were not fed, and the water was not changed during exposure.

2.3.2. Determination of Toxic Effects in D. magna. After $48 \mathrm{~h}$ of exposure, living daphnids were collected from each treatment and treated similar to the treatment in our previous study [13]. Ten to fifteen daphnids were subsequently dried at $80^{\circ} \mathrm{C}$ to a constant weight and then digested in $68 \%$ nitric acid $\left(\mathrm{HNO}_{3}\right.$, Aristar grade) at $110^{\circ} \mathrm{C}$. The digestion solution was used to determine $\mathrm{Zn}$ accumulation in $D$. magna by using ICP-MS. The remaining 15 to 20 daphnids were immediately weighed on a wet basis. The daphnid tissues were homogenized through ultrasonication in $0.5 \mathrm{~mL}$ of sucrose buffer $\left(0.25 \mathrm{~mol} \mathrm{~L}^{-1}\right.$ sucrose, $0.1 \mathrm{~mol} \mathrm{~L}^{-1}$ Tris- $\mathrm{HCl}$, and $\left.\mathrm{pH} 8.6\right)$ and then centrifuged at $12000 \times \mathrm{g}$ in a refrigerated centrifuge for $20 \mathrm{~min}$. The supernatant was collected and diluted with a homogenate of $1.5 \mathrm{~mL}$. The $0.5 \mathrm{~mL}$ of diluted supernatant fluid was mixed with $\mathrm{Ag}^{+}$solution for MT measurement according to the modified silver saturation method [14]. Thereafter, $0.2 \mathrm{~mL}$ of the aforementioned diluted supernatant fluid was used to measure MDA by using a spectrophotometer according to the manufacturer's instructions. MDA contents in D. magna were assayed using commercially available kits according to the manufacturer's protocol (Nanjing Jiancheng Bioengineering Institute, China). The analysis of MT and MDA contents was completed within $3 \mathrm{~d}$ after $48 \mathrm{~h}$ of exposure.

\section{Results and Discussion}

\subsection{Characterization of Five $\mathrm{nZnO}$ Photocatalysts}

3.1.1. Morphology of Five $\mathrm{nZnO}$ Photocatalysts. Images of $\mathrm{nZnO}$ dispersion in water were characterized by TEM, as shown in Figure 1. The Mn-nZnO was a rod with nanosized diameter and microsized length. The remaining $\mathrm{nZnO}$ materials were particles. Fe-nZnO had the smallest particle size (approximately $20 \mathrm{~nm}$ ) with a uniform shape. The sizes of Co-nZnO, Ni-nZnO, and nondoped $\mathrm{nZnO}$ were between 


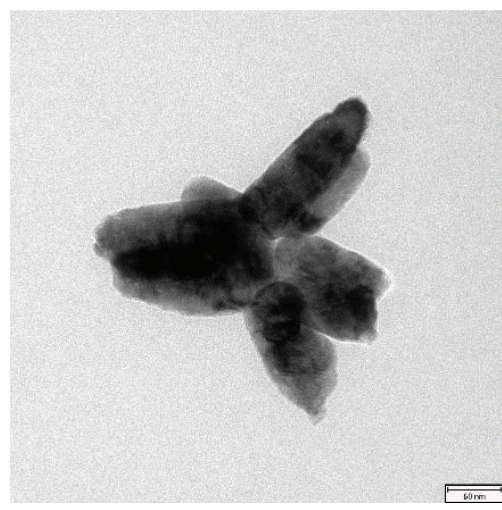

(a)

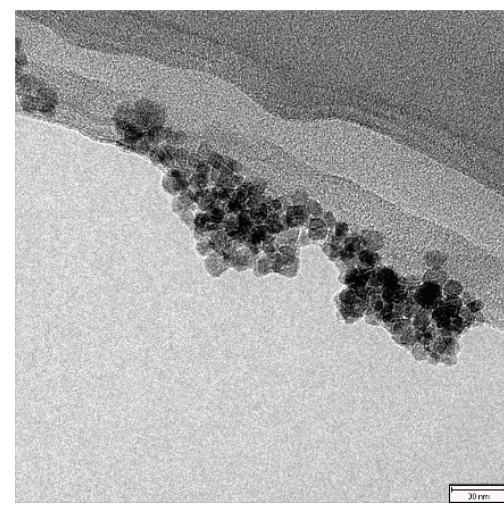

(b)



(c)

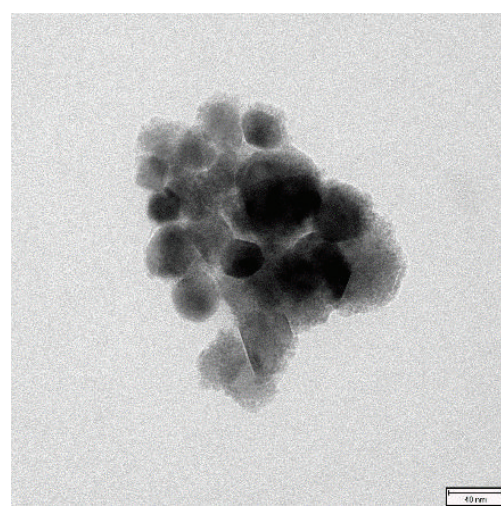

(d)

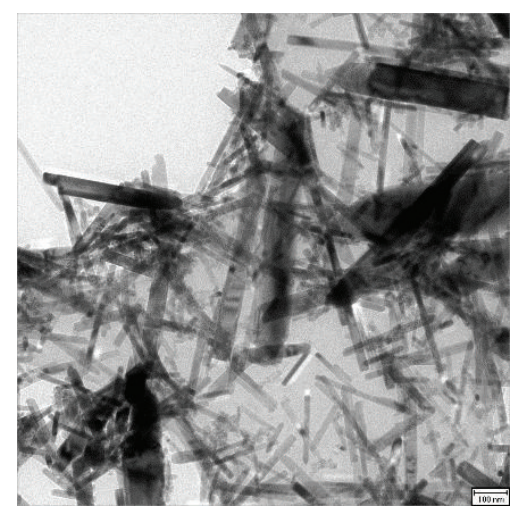

(e)

Figure 1: TEM images of different doped nZnO photocatalysts. (a) Nondoped nZnO, (b) Fe-nZnO, (c) Co-nZnO, (d) Ni-nZnO, and (e) $\mathrm{Mn}-\mathrm{nZnO}$.

40 and $100 \mathrm{~nm}$. All the five types of $\mathrm{nZnO}$ materials tended to aggregate in water, especially for $\mathrm{Mn}-\mathrm{nZnO}$. The table of ionic radius showed that the radius of $\mathrm{Zn}^{2+}$ was $0.074 \mathrm{~nm}$, that of $\mathrm{Fe}^{3+}$ was $0.0645 \mathrm{~nm}$, that of $\mathrm{Co}^{2+}$ was $0.074 \mathrm{~nm}$, that of $\mathrm{Ni}^{2+}$ was $0.072 \mathrm{~nm}$, and that of $\mathrm{Mn}^{2+}$ was $0.08 \mathrm{~nm}$. These results may explain why $\mathrm{Fe}-\mathrm{nZnO}$ had the smallest particle size, whereas Mn-nZnO had the largest. Xia et al. [11] also proved that Fe doping can reduce $\mathrm{nZnO}$ size.

\subsubsection{Dissolubility of Five $n \mathrm{ZnO}$ Photocatalysts in Natural} Water. Figure 2 shows the percentage content of dissolved $\mathrm{Zn}^{2+}$ in the supernatant of each natural water sample, which indicated that $\mathrm{nZnO}$ exhibited certain solubility in water. However, the dissolved $\mathrm{Fe}, \mathrm{Co}, \mathrm{Ni}$, and $\mathrm{Mn}$ were not detected because their contents were under the detection limit of ICP-MS. When the $\mathrm{nZnO}$ concentration was $100 \mu \mathrm{g} \mathrm{L}^{-1}$, the dissolved $\mathrm{Zn}^{2+}$ content of each sample was lower than $2 \%$ at $240 \mathrm{~min}$. This solubility was considerably lower than that in Franklin's study, which determined the solubility of $\mathrm{nZnO}$ in natural water at $100 \mathrm{mg} \mathrm{L}^{-1}$ in $72 \mathrm{~h} \mathrm{[15].} \mathrm{The} \mathrm{solubility} \mathrm{of}$ $\mathrm{nZnO}$ might be influenced by nominal $\mathrm{nZnO}$ concentration and testing period. Moreover, the solubility of $\mathrm{Mn}-\mathrm{nZnO}$ and $\mathrm{Fe}-\mathrm{nZnO}$ was significantly higher than that of other $\mathrm{nZnO}$. Nevertheless, the solubility of $\mathrm{Ni}-\mathrm{nZnO}$ was similar to that of the nondoped $\mathrm{nZnO}$. In addition, the solubility of Co-nZnO

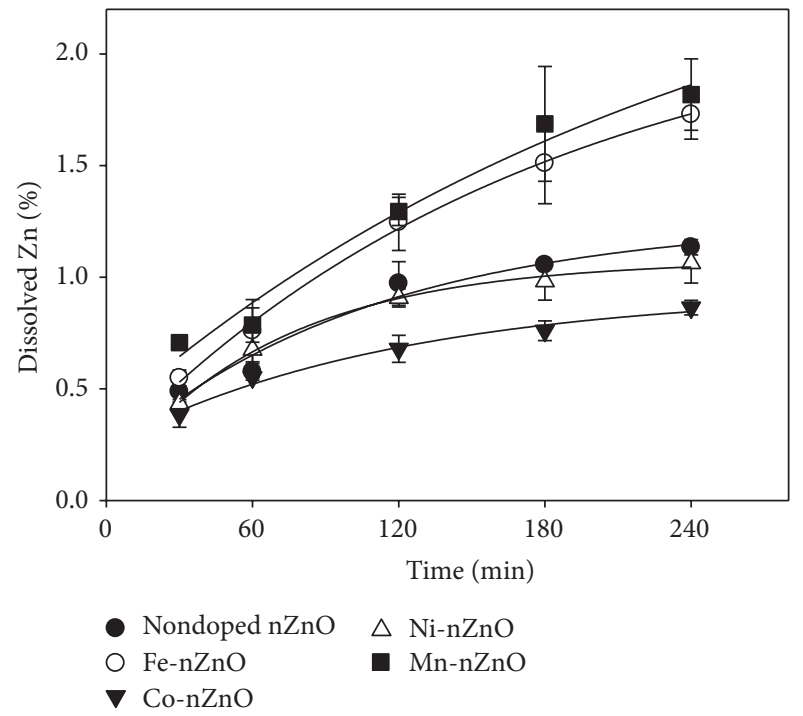

FIgURE 2: Dissolution of different doped $\mathrm{nZnO}$ photocatalysts in natural water. Mean \pm standard deviation $(n=2)$.

was lower than $1 \%$, which was the lowest among the five kinds of $\mathrm{nZnO}$. These results indicate that different doped metals changed the solubility of $\mathrm{nZnO}$. However, the solubility of Fedoped $\mathrm{nZnO}$ from this study was different from that in the 


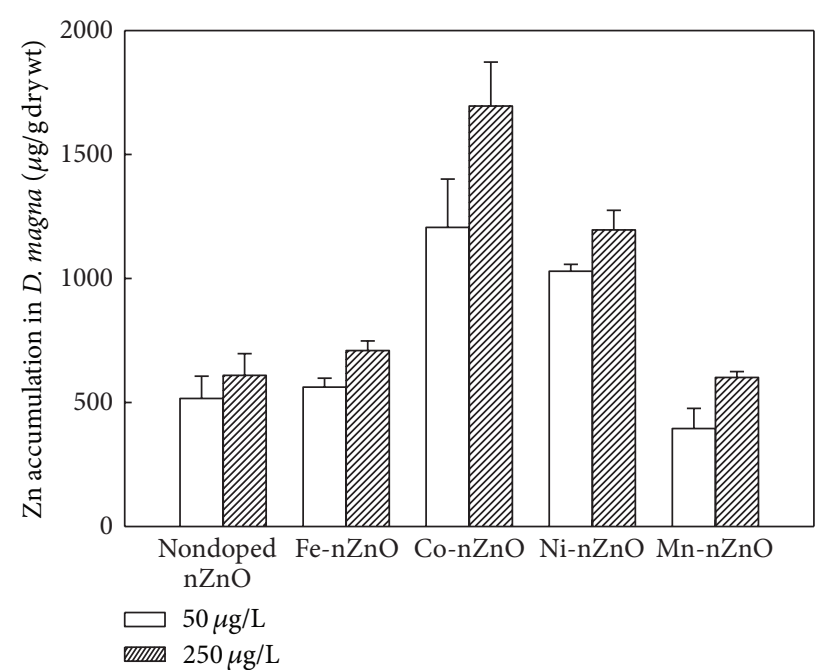

FIgURE 3: Zn accumulation in D. magna after exposure to different doped $\mathrm{nZnO}$ photocatalysts. Mean \pm standard deviation $(n=2)$.

study of Xia et al. [11]. This condition might be attributed to the different synthesis nZnO methods. The synthesis method of Xia et al. was flame spray pyrolysis, whereas our method was a wet chemical method. Miao's study also indicated that several physicochemical factors have to be considered in $\mathrm{nZnO}$ dissolution behavior.

\subsection{Biotoxicity of Five $n Z n O$ Photocatalysts to D. magna}

3.2.1. Bioaccumulation of $\mathrm{Zn}$ in D. magna. $\mathrm{Zn}$ accumulation in D. magna after exposure to five different $\mathrm{nZnO}$ photocatalysts was measured, as shown in Figure 3. The high-concentration exposure groups of all types of $\mathrm{nZnO}$ had higher $\mathrm{Zn}$ accumulation than the low-concentration exposure groups. Zn accumulation was $156 \mu \mathrm{g} / \mathrm{g}$ dry wt in nonexposure D. magna, significantly lower than that in the $\mathrm{nZnO}$ exposure groups. No apparent difference was observed in the $\mathrm{Zn}$ accumulation in D. magna after exposure to nondoped $\mathrm{nZnO}, \mathrm{Fe}-\mathrm{nZnO}$, and $\mathrm{Mn}-\mathrm{nZnO}(400-700 \mu \mathrm{g} / \mathrm{g}$ dry wt). While exposed to Co-nZnO and Ni-nZnO, the $\mathrm{Zn}$ accumulation in D. magna was higher than $1,000 \mu \mathrm{g} / \mathrm{g}$ dry wt. D. magna is a filter feeding organism that can swallow a range of sizes of nanoparticle clusters [17]. Nano-ZnO, especially $\mathrm{Mn}-\mathrm{nZnO}$ rods, tended to aggregate in water. $\mathrm{Mn}$ $\mathrm{nZnO}$, which had a larger size and poorer dispersion, more easily sank to the bottom of the container and was not conducive for D. magna to adsorb, which might be the reason why $\mathrm{Mn}-\mathrm{nZnO}$ treatment exhibited the least accumulation in daphnids after $48 \mathrm{~h}$ of exposure. Zn accumulation in Codoped exposure groups was significantly higher than that in the other groups because of the large intestinal particle aggregation, which was difficult to excrete (Figure 4(c)).

To explore the states of existence of $\mathrm{nZnO}$ in D. magna, intestinal slices of daphnids exposed to $\mathrm{nZnO}$ particles were observed by SEM (JSM-6380) with an EDAX-Genesis-2000 energy X-ray dispersive spectrometer. D. magna was prepared before dissection according to the method described by Tervonen et al. [18]. As shown in Figure 4, the existing particles at the root of the D. magna intestinal villi were observed. Energy dispersive X-ray spectroscopy (EDS) elemental analysis showed that these particles are the exposed $\mathrm{ZnO}$ nanoparticles. The doping elements $\mathrm{Fe}, \mathrm{Co}$, and $\mathrm{Mn}$ were identified in the corresponding intestinal slice samples. In the intestinal slice sample of Ni-nZnO treatment, Fe was detected instead of $\mathrm{Ni}$ because the proportion of $\mathrm{Ni}$ was low at the detected point and the Fe content was high in air and natural water.

3.2.2. Induction of Metallothioneins by Five $n Z n O s$. MT is a cysteine-rich metal binding protein with low molecular weight, which can combine some essential trace metals, such as $\mathrm{Zn}$ and $\mathrm{Cu}$, as well as nonessential toxic metals, such as $\mathrm{Cd}, \mathrm{Hg}$, and $\mathrm{Ag}$ in cells [19]. Therefore, MT regulates the intracellular metal concentration and protects cells from toxic effects. As a biomarker, the MT contents of D. magna, in response to $\mathrm{nZnO}$ exposure, are shown in Figure 5. MT inductions were between 30 and $40 \mu \mathrm{g} / \mathrm{g}$ wet wt in the lowconcentration exposure groups and 40 and $50 \mu \mathrm{g} / \mathrm{g}$ wet wt in the high-concentration exposure groups. A minor difference was observed between the two concentration groups, which was similar to the results obtained by Wong et al. [20]. Comparing five different $\mathrm{nZnOs,} \mathrm{MT}$ inductions caused by $\mathrm{Ni}-\mathrm{nZnO}$ were slightly higher than those by nondoped $\mathrm{nZnO}$ exposure groups, whereas $\mathrm{Fe}-$, $\mathrm{Co}-$, and $\mathrm{Mn}$-doped $\mathrm{nZnO}$ decreased such inductions in the daphnids to a small degree. Binding to the excess metal ions was usually believed to be a protection mechanism of MT during metal exposure. Low dissolubility of the five types of $\mathrm{nZnO}$ might be a reason for the lack of a significant difference in MT content.

3.2.3. MDA Levels in D. magna after Exposure to Five $n \mathrm{ZnO}$ s. MDA is a product of lipid oxidation caused by reactive oxygen species (ROS) attacking unsaturated fatty acids (PUFA) in biofilms [21]. The amount of MDA reflected the body lipid peroxidation levels, thus indirectly reflecting the degree of cell damage [22]. MDA contents of D. magna without nanomaterials exposure were measured to be approximately $10 \mathrm{nmol} / \mathrm{mgprot}$. Figure 6 shows the MDA contents of $D$. magna after exposure to $\mathrm{nZnO}$ particles. The MDA contents were between 20 and $30 \mathrm{nmol} / \mathrm{mgprot}$ in $50 \mu \mathrm{g} \mathrm{L} \mathrm{L}^{-1}$ exposure groups (i.e., twice to thrice that of the control) and between 40 and $50 \mathrm{nmol} / \mathrm{mgprot}_{\text {in }} 250 \mu \mathrm{g} \mathrm{L}{ }^{-1}$ exposure groups (i.e., four to five times that of the control). That is, the MDA contents of the high-concentration groups were 1.5 to two times that of the low-concentration groups after $\mathrm{nZnO}$ exposure. These results indicated that these five types of $\mathrm{nZnO}$ can cause serious lipid peroxidation, and this extent of damage expanded rapidly with increasing exposure concentration. At the same concentration, the $\mathrm{Ni}$-doped $\mathrm{nZnO}$ exposure group has similar MDA levels to the nondoped $\mathrm{nZnO}$ exposure group, whereas the doping of $\mathrm{Fe}, \mathrm{Co}$, and $\mathrm{Mn}$ reduced MDA contents. This finding indicates that the doping elements changed the bioeffects of $\mathrm{nZnO}$. Previous studies found that doping of $\mathrm{Co}$ [23] and $\mathrm{Mn}$ [24] in $\mathrm{ZnO}$ influenced the antibacterial property of $\mathrm{nZnO}$. 


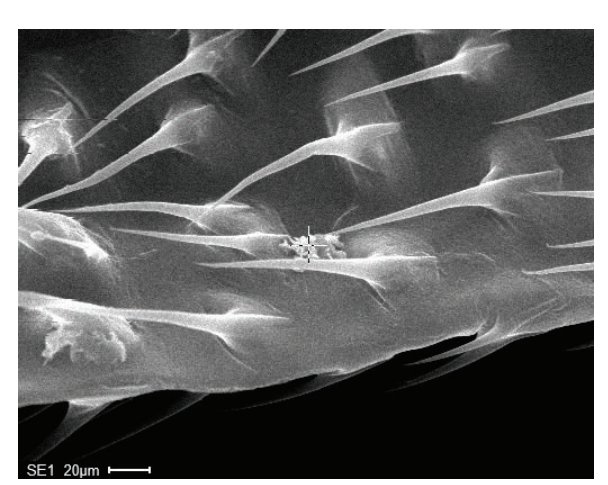

(a)

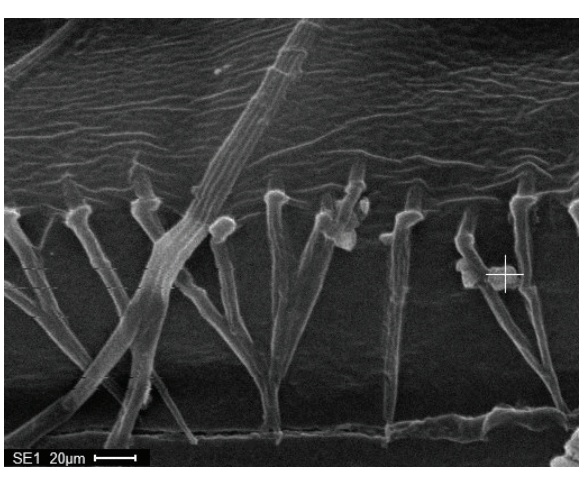

(b)

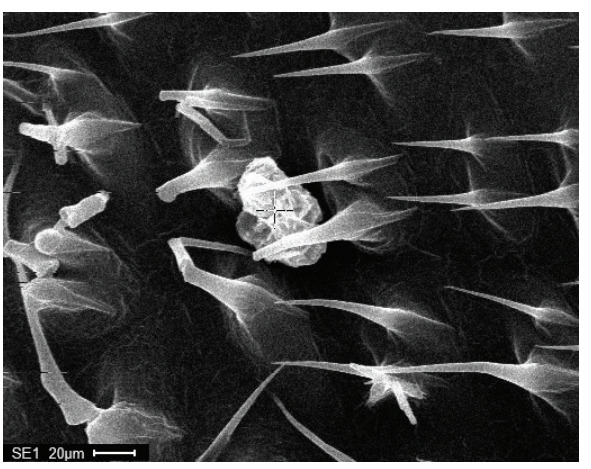

(c)

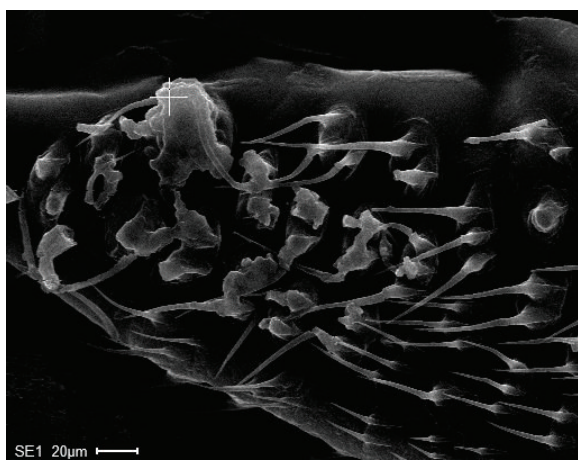

(d)

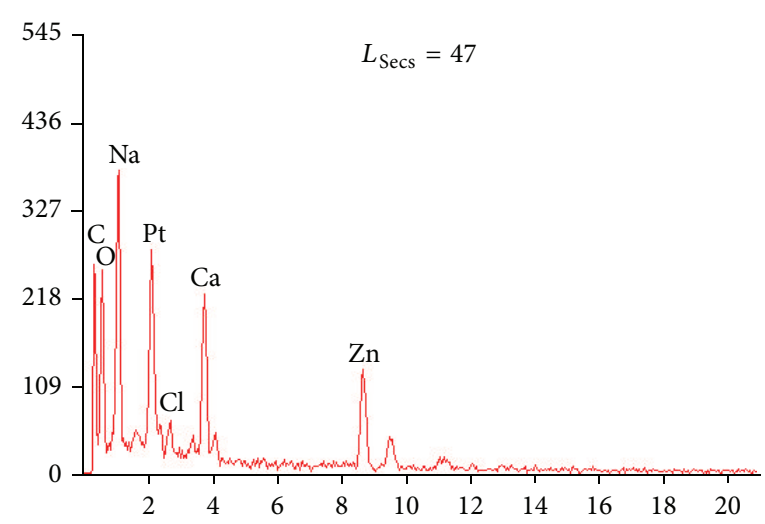

(A)

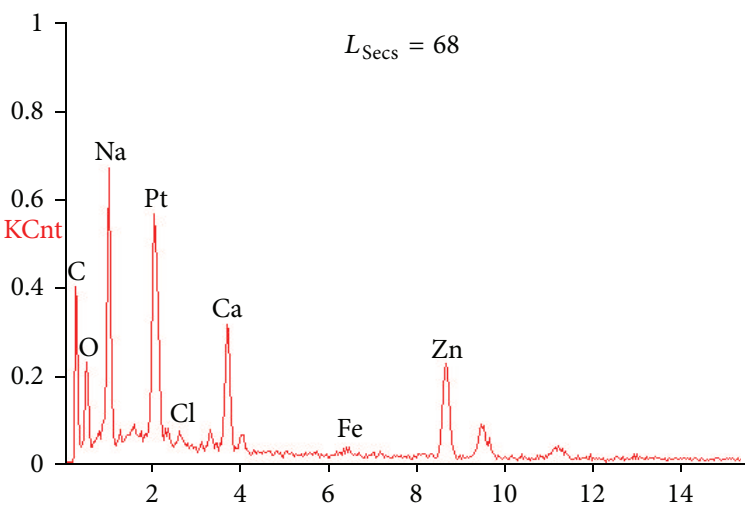

(B)

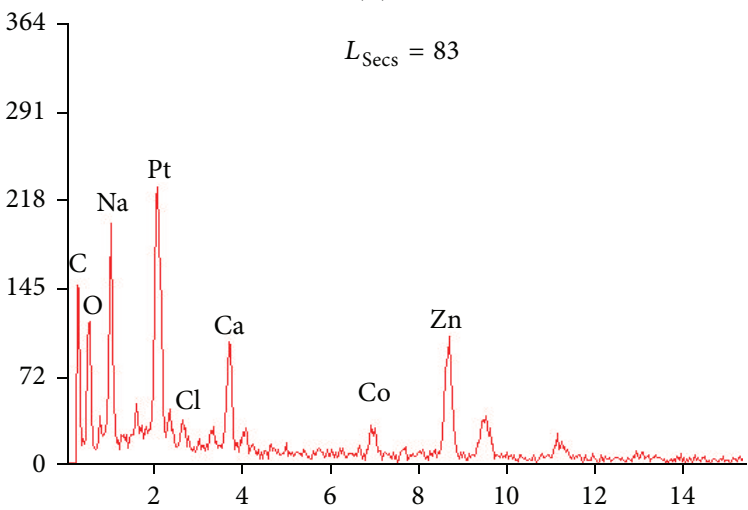

(C)

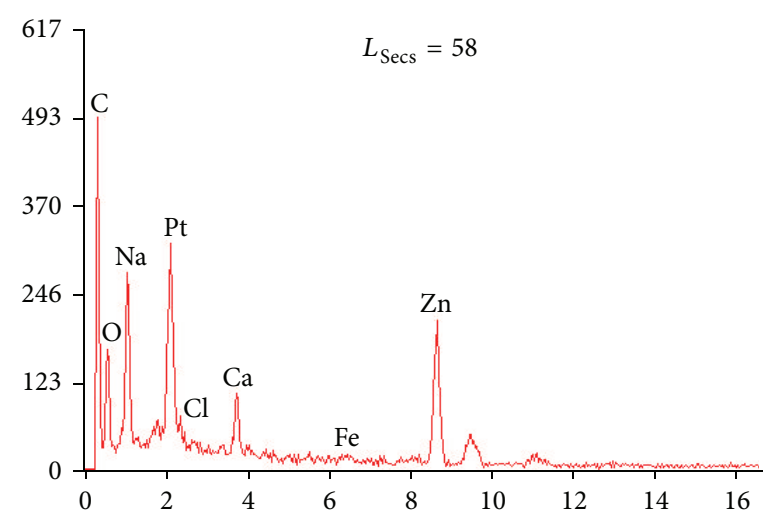

(D)

Figure 4: Continued. 


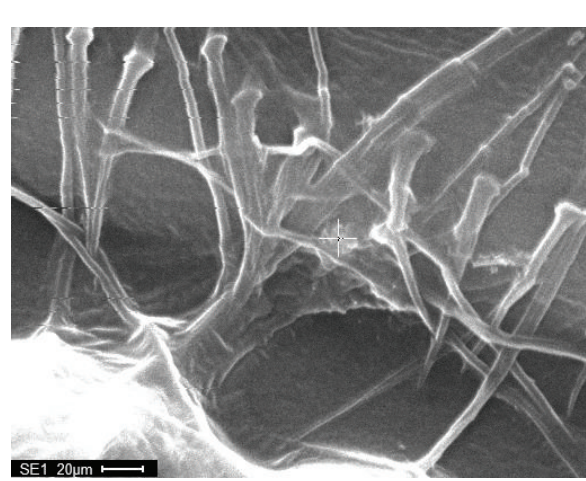

(e)

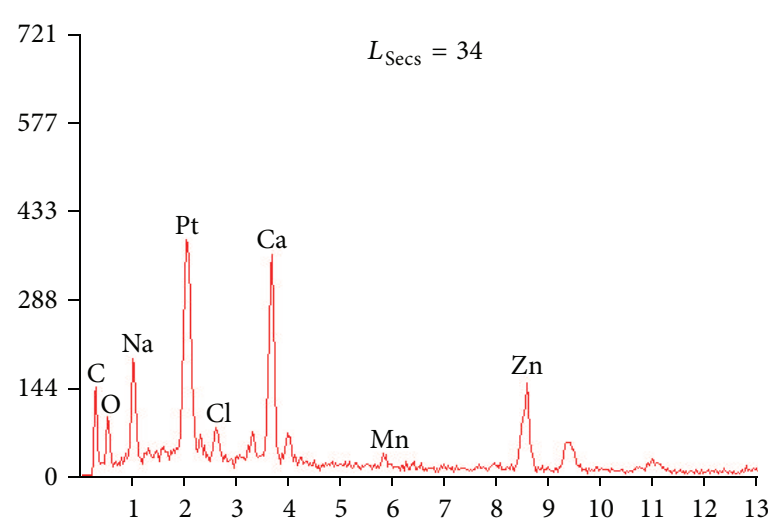

(E)

FIGURE 4: SEM images and microanalysis by an energy dispersive spectrometer of accumulated nZnO in the intestines of $D$. magna after $2 \mathrm{~d}$ exposure. (A, a) Nondoped nZnO, (B, b) Fe-nZnO, (C, c) Co-nZnO, (D, d) Ni-nZnO, and (E, e) Mn-nZnO.

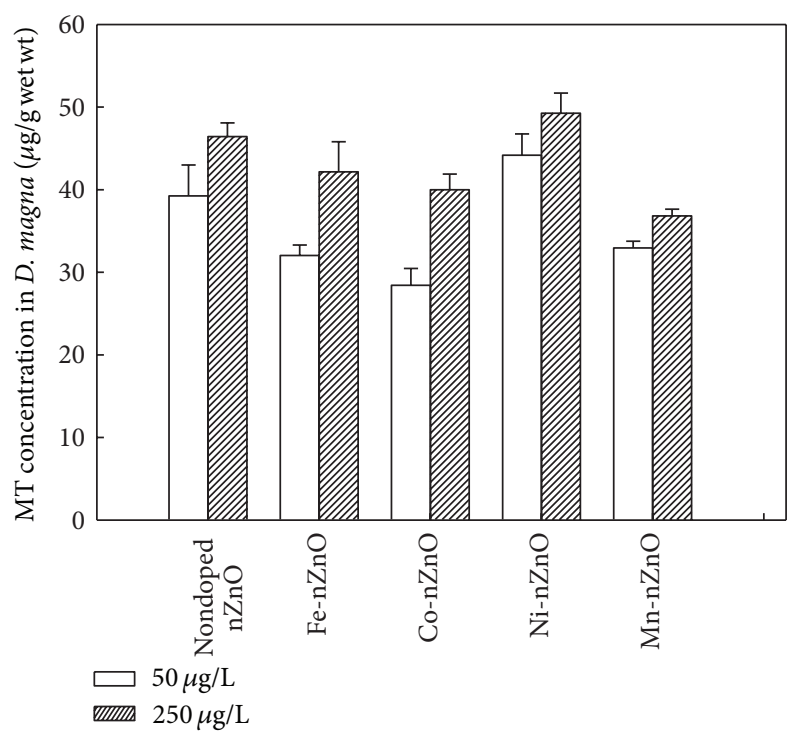

Figure 5: MT induction of D. magna after exposure to different doped $\mathrm{nZnO}$ photocatalysts. Mean \pm standard deviation $(n=2)$.

3.3. Relationship of the Dissolubility of Five $n \mathrm{ZnO}$ Photocatalysts with the Biotoxicity to D. magna. As previously discussed, five $\mathrm{nZnO}$ (nondoped $\mathrm{nZnO}, \mathrm{Fe}-\mathrm{nZnO}, \mathrm{Co}-\mathrm{nZnO}$, $\mathrm{Ni}-\mathrm{nZnO}$, and $\mathrm{Mn}-\mathrm{nZnO}$ ) photocatalysts showed varying dissolubility in natural water and toxic effects to D. magna, and their relationships were investigated in Figure 7. A negative relationship was observed between dissolved $\mathrm{Zn}$ percentage and $\mathrm{Zn}$ accumulation in D. magna, as shown in Figure 7(a). This finding indicates that the ingestion of $\mathrm{Zn}^{2+}$ from aqueous phase was not the main uptake behavior in this study. $\mathrm{Zn}$ accumulation was distinctive under different metaldoped $\mathrm{nZnO}$, which might be because of the dissolved $\mathrm{Zn}^{2+}$, different aggregation clusters of $\mathrm{M}-\mathrm{nZnO}$, and particularities of doping metals. As for soluble Ag nanoparticles, the results of the uptake experiments showed that water drinking was an important pathway to obtain AgNPs in the medium for $D$.

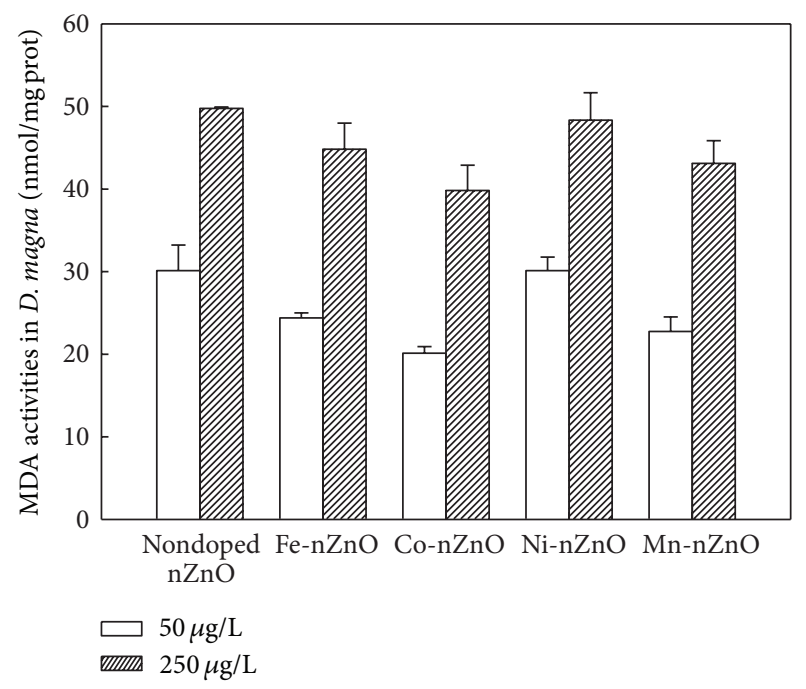

FIgURE 6: MDA activities of $D$. magna after exposure to different doped $\mathrm{nZnO}$ photocatalysts. Mean \pm standard deviation $(n=2)$.

magna [25]. On the contrary, MT and MDA contents were independent of the dissolved $\mathrm{Zn}$ percentage in the medium (Figures 7(b) and 7(c)). Among all the metals in this study, only $\mathrm{Zn}$ can induce the generation of MT. Thus, the MT contents were correlated with the concentration of free $\mathrm{Zn}^{2+}$ in the body instead of external mediums. One important toxicity mechanism of $\mathrm{nZnO}$ photocatalysts was oxidative damage by ROS. Meanwhile, MDA reflected the degree of lipid peroxidation and was influenced by many factors. In this study, physiological functions of doping metals might alleviate the biotoxicity of $\mathrm{M}-\mathrm{nZnO}$ photocatalysts to various extents. Fe, Co, $\mathrm{Zn}$, and $\mathrm{Mn}$ are essential elements that have important effects on the growth of organisms [26]. During the experiment process, parts of the doped Fe, Co, and Mn dissolved into the medium despite being undetected. The release of trace metals can supply nutrition for D. magna under short-term exposure. 


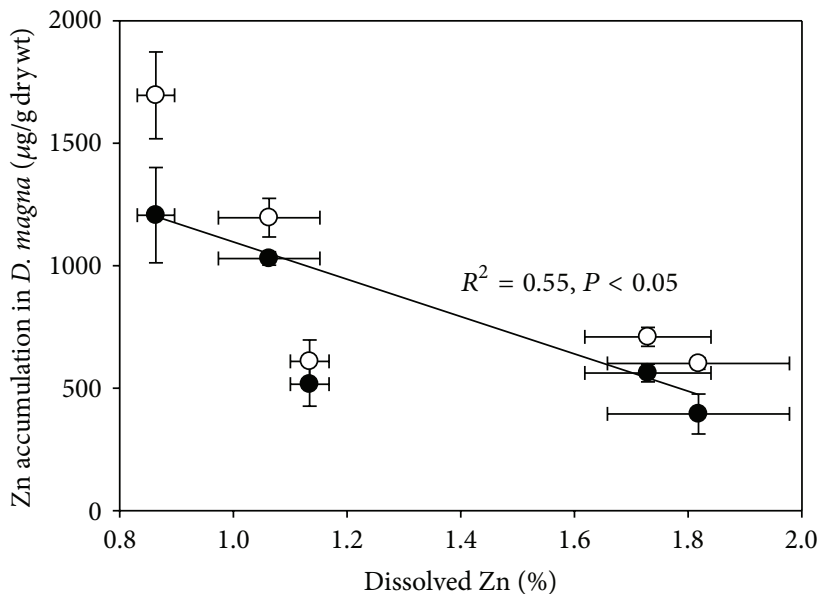

(a)

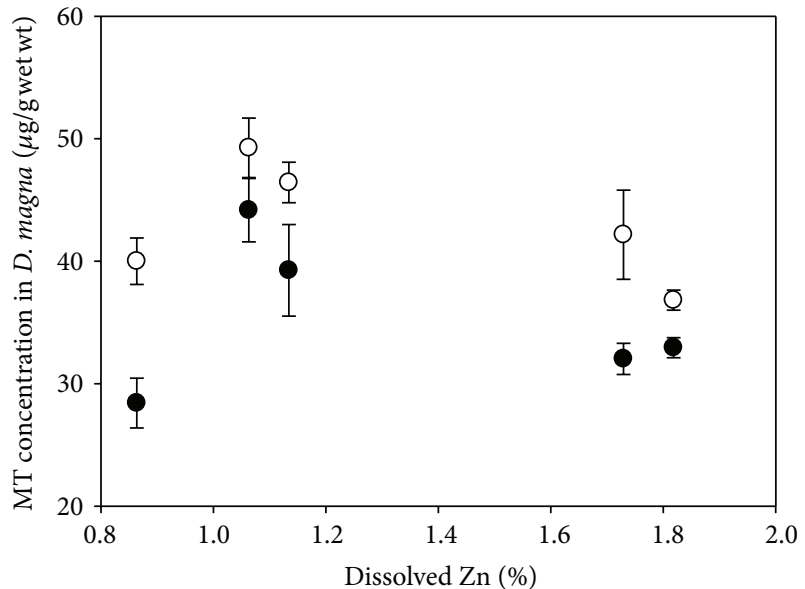

(b)

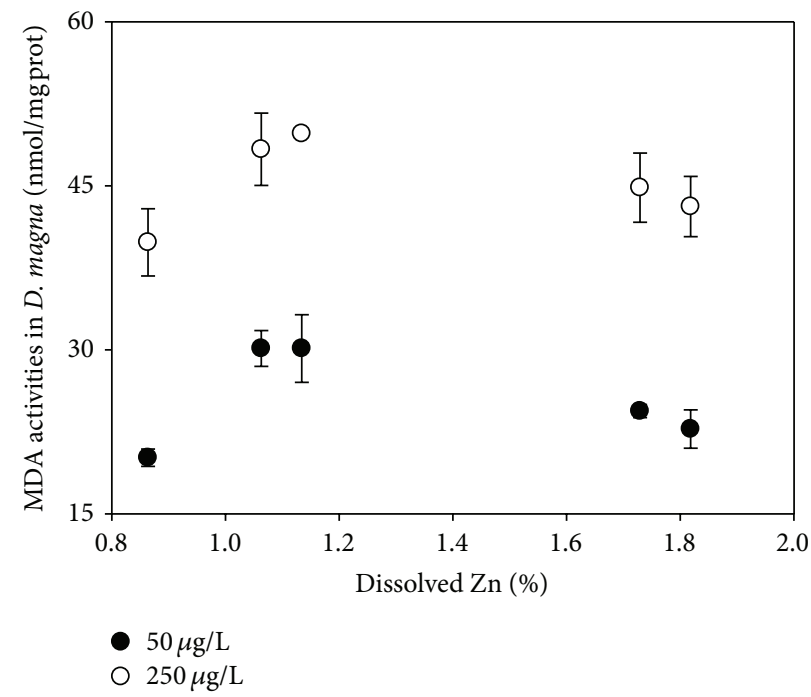

(c)

FIGURE 7: Relationships between dissolubility of five $\mathrm{nZnO}$ photocatalysts and toxic effects in D. magna. (a) Zn accumulation, (b) MT concentration, and (c) MDA activity.

\section{Conclusions}

Metal-doped nZnO (Fe-nZnO, Co-nZnO, Ni-nZnO, and $\mathrm{Mn}-\mathrm{nZnO}$ ) and nondoped $\mathrm{nZnO}$ photocatalysts were prepared through hydrothermal method of zinc nitrate, hexamethylenetetramine, and various metal ions. The morphologies and dissolubility of five $\mathrm{nZnO}$ photocatalysts were diverse because of the doping metals. Moreover, metal-doped $\mathrm{nZnO}$ photocatalysts changed toxic effects in D. magna compared with nondoped nZnO. Co-doped and Ni-doped $\mathrm{nZnO}$ enhanced $\mathrm{Zn}$ accumulation in daphnids, whereas Mn-doped $\mathrm{nZnO}$ reduced such accumulation. Biomarkers, such as MT and MDA contents, in metal-doped $\mathrm{nZnO}$ treatments, except for $\mathrm{Ni}-\mathrm{nZnO}$, were lower than those in nondoped $\mathrm{nZnO}$. $\mathrm{Zn}$ accumulation showed a negative relationship with dissolved $\mathrm{Zn}$ percentage, which indicated that $\mathrm{Zn}^{2+}$ was not the only pathway of D. magna ingestion. By contrast, MT and MDA contents in organisms were dependent on the dose of $\mathrm{nZnO}$ exposure rather than on dissolubility. When considering the biotoxicity of metal-doped $\mathrm{nZnO}$ photocatalysts, physiological functions of doping metals should not be ignored.

\section{Conflict of Interests}

The authors declare that there is no conflict of interests regarding the publication of this paper.

\section{Authors' Contribution}

Both Lingling Liu and XiangRui Wang contributed equally to this work.

\section{Acknowledgments}

This work was supported by the National Natural Science Foundation of China (nos. 51378041 and 51290283) and 
Specialized Research Fund for the Doctoral Program of Higher Education (no. 20131102110035).

\section{References}

[1] Z. Fan and J. G. Lu, "Zinc oxide nanostructures: synthesis and properties," Journal of Nanoscience and Nanotechnology, vol. 5, no. 10, pp. 1561-1573, 2005.

[2] Z. L. Wang, "Zinc oxide nanostructures: growth, properties and applications," Journal of Physics Condensed Matter, vol. 16, no. 25, pp. 829-858, 2004.

[3] Z. S. Seddigi, S. A. Ahmed, S. P. Ansari, E. Danish, A. A. Alkibash, and S. Ahmed, "Kinetics and photodegradation study of aqueous methyl tert-butyl ether using zinc oxide: the effect of particle size," International Journal of Photoenergy, vol. 2013, Article ID 206129, 7 pages, 2013.

[4] J. G. Yu and X. X. Yu, "Hydrothermal synthesis and photocatalytic activity of zinc oxide hollow spheres," Environmental Science and Technology, vol. 42, no. 13, pp. 4902-4907, 2008.

[5] C. Shifu, Z. Wei, Z. Sujuan, and L. Wei, "Preparation, characterization and photocatalytic activity of $\mathrm{N}$-containing $\mathrm{ZnO}$ powder," Chemical Engineering Journal, vol. 148, no. 2-3, pp. 263-269, 2009.

[6] M. C. Chang, H. Y. Shu, T. H. Tseng, and H. W. Hsu, "Supported zinc oxide photocatalyst for decolorization and mineralization of orange G dye wastewater under UV365 irradiation," International Journal of Photoenergy, vol. 2013, Article ID 595031, 12 pages, 2013.

[7] C. Xu, L. X. Cao, G. Su, W. Liu, X. F. Qu, and Y. Q. Yu, "Preparation, characterization and photocatalytic activity of Co-doped ZnO powders," Journal of Alloys and Compounds, vol. 497, no. 1-2, pp. 373-376, 2010.

[8] R. Ullah and J. Dutta, "Photocatalytic degradation of organic dyes with manganese-doped $\mathrm{ZnO}$ nanoparticles," Journal of Hazardous Materials, vol. 156, no. 1-3, pp. 194-200, 2008.

[9] S. J. Klaine, P. J. J. Alvarez, G. E. Batley et al., "Nanomaterials in the environment: behavior, fate, bioavailability, and effects," Environmental Toxicology and Chemistry, vol. 27, no. 9, pp. 18251851, 2008.

[10] H. Ma, P. L. Williams, and S. A. Diamond, "Ecotoxicity of manufactured $\mathrm{ZnO}$ nanoparticles-a review, Environmental Pollution, vol. 172, pp. 76-85, 2013.

[11] T. Xia, Y. Zhao, T. Sager et al., "Decreased dissolution of $\mathrm{ZnO}$ by iron doping yields nanoparticles with reduced toxicity in the rodent lung and zebrafish embryos," ACS Nano, vol. 5, no. 2, pp. 1223-1235, 2011.

[12] A. Wang, B. Zhang, X. Wang et al., "Nano-structure, magnetic and optical properties of Co-doped $\mathrm{ZnO}$ films prepared by a wet chemical method," Journal of Physics D: Applied Physics, vol. 41, no. 21, Article ID 215308, 2008.

[13] W. H. Fan, Z. W. Shi, X. P. Yang et al., "Bioaccumulation and biomarker responses of cubic and octahedral $\mathrm{Cu}_{2} \mathrm{O}$ micro/nanocrystals in Daphnia magna," Water Research, vol. 46, no. 18, pp. 5981-5988, 2012.

[14] W. H. Fan, G. Tang, C. M. Zhao, Y. Duan, and R. Zhang, "Metal accumulation and biomarker responses in Daphnia magna following cadmium and zinc exposure," Environmental Toxicology and Chemistry, vol. 28, no. 2, pp. 305-310, 2009.

[15] N. M. Franklin, N. J. Rogers, S. C. Apte, G. E. Batley, G. E. Gadd, and P. S. Casey, "Comparative toxicity of nanoparticulate $\mathrm{ZnO}$, bulk $\mathrm{ZnO}$, and $\mathrm{ZnCl} 2$ to a freshwater microalga
(Pseudokirchneriella subcapitata): the importance of particle solubility," Environmental Science and Technology, vol. 41, no. 24, pp. 8484-8490, 2007.

[16] A. J. Miao, X. Y. Zhang Z. Luo et al., "Zinc oxide-engineered nanoparticles: dissolution and toxicity to marine phytoplankton," Environmental Toxicology and Chemistry, vol. 29, no. 12, pp. 2814-2822, 2010.

[17] C. Tan, W. H. Fan, and W. X. Wang, "Role of titanium dioxide nanoparticles in the elevated uptake and retention of cadmium and zinc in Daphnia magna," Environmental Science and Technology, vol. 46, no. 1, pp. 469-476, 2012.

[18] K. Tervonen, G. Waissi, E. J. Petersen, J. Akkanen, and J. V. K. Kukkonen, "Analysis of fullerene-C60 and kinetic measurements for its accumulation and depuration in Daphnia magna," Environmental Toxicology and Chemistry, vol. 29, no. 5, pp. 1072-1078, 2010.

[19] J. C. Amiard, C. Amiard-Triquet, S. Barka, J. Pellerin, and P. S. Rainbow, "Metallothioneins in aquatic invertebrates: their role in metal detoxification and their use as biomarkers," Aquatic Toxicology, vol. 76, no. 2, pp. 160-202, 2006.

[20] S. W. Y. Wong, P. T. Y. Leung, A. B. Djurišić, and K. M. Y. Leung, "Toxicities of nano zinc oxide to five marine organisms: influences of aggregate size and ion solubility," Analytical and Bioanalytical Chemistry, vol. 396, no. 2, pp. 609-618, 2010.

[21] J. Pilz, I. Meineke, and C. H. Gleiter, "Measurement of free and bound malondialdehyde in plasma by high-performance liquid chromatography as the 2,4-dinitrophenylhydrazine derivative," Journal of Chromatography B: Biomedical Sciences and Applications, vol. 742, no. 2, pp. 315-325, 2000.

[22] W. H. Fan, X. L. Wang, M. M. Cui et al., "Differential oxidative stress of octahedral and cubic $\mathrm{Cu}_{2} \mathrm{O}$ micro/nanocrystals to Daphnia magna," Environmental Science and Technology, vol. 46, pp. 10255-10262, 2012.

[23] M. G. Nair, M. Nirmala, K. Rekha, and A. Anukaliani, "Structural, optical, photo catalytic and antibacterial activity of $\mathrm{ZnO}$ and Co doped ZnO nanoparticles," Materials Letters, vol. 65, no. 12, pp. 1797-1800, 2011.

[24] K. Rekha, M. Nirmala, M. G. Nair, and A. Anukaliani, "Structural, optical, photocatalytic and antibacterial activity of zinco xide and manganese doped zinc oxide nanoparticles," Physica B: Condensed Matter, vol. 405, no. 15, pp. 3180-3185, 2010.

[25] C. M. Zhao and W. X. Wang, "Size-dependent uptake of silver nanoparticles in Daphnia magna," Environmental Science and Technology, vol. 46, pp. 11345-11351, 2012.

[26] M. N. Hughes and R. K. Poole, "Metal speciation and microbial growth-the hard (and soft) facts," Journal of General Microbiology, vol. 137, no. 4, pp. 725-734, 1991. 

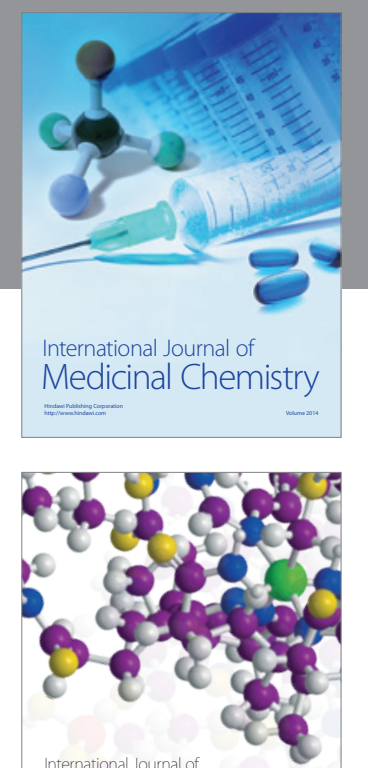

\section{Carbohydrate} Chemistry

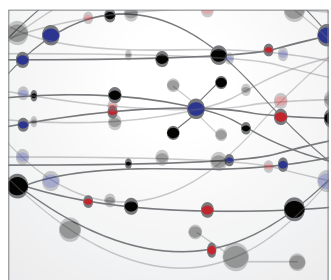

The Scientific World Journal
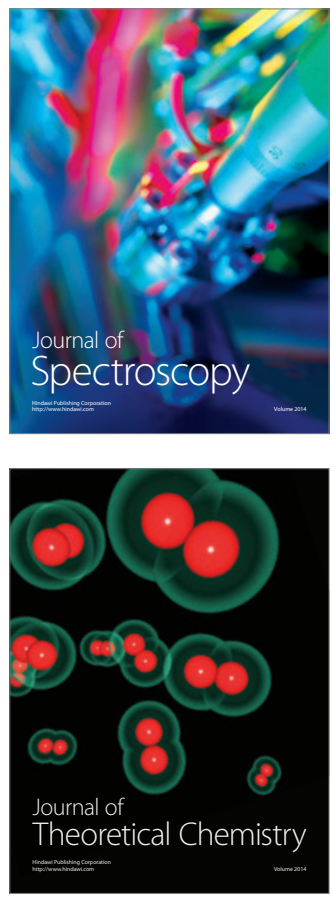
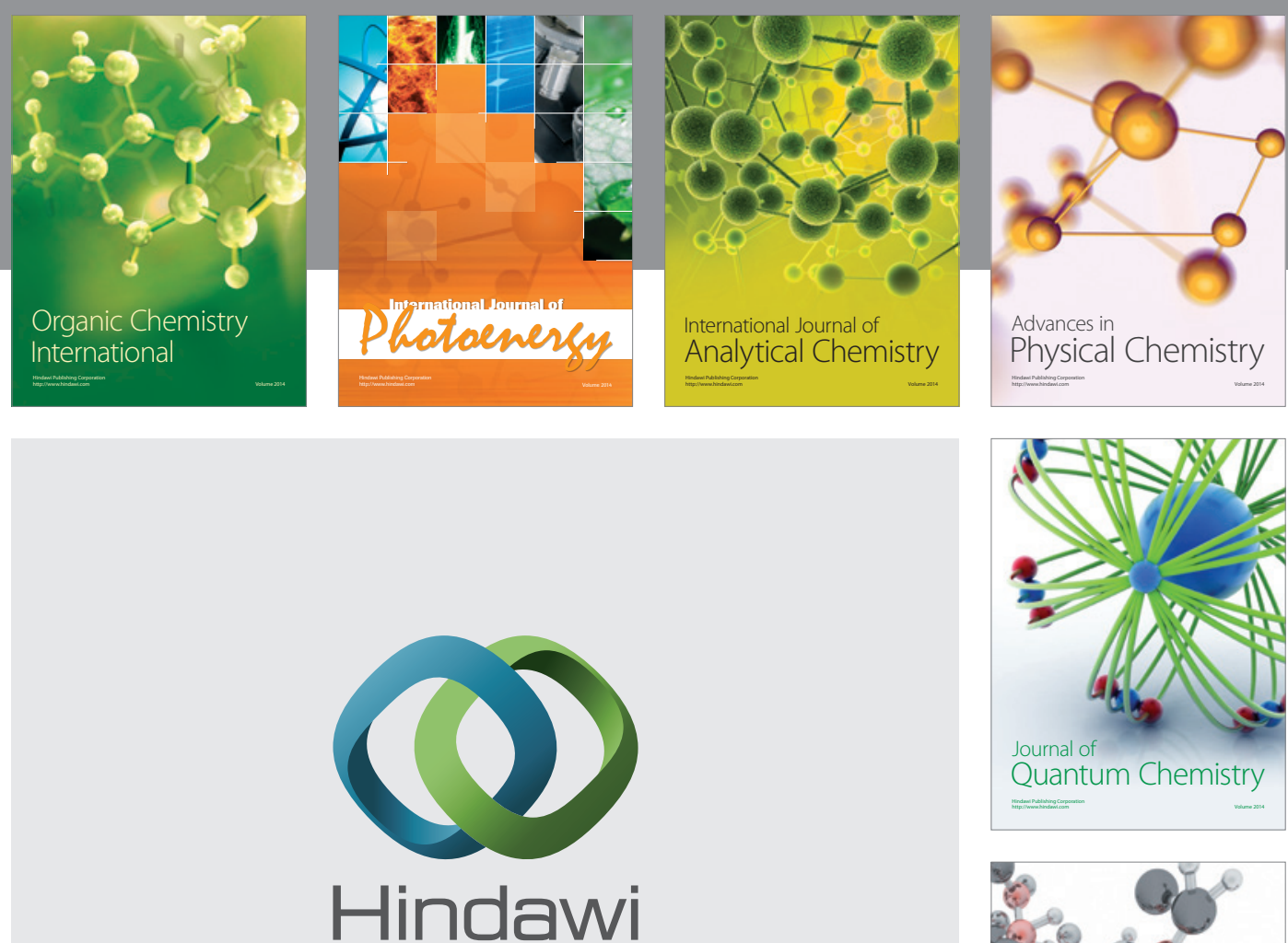

Submit your manuscripts at

http://www.hindawi.com

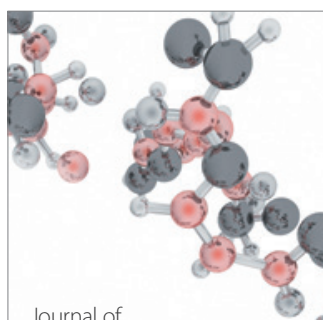

Analytical Methods

in Chemistry

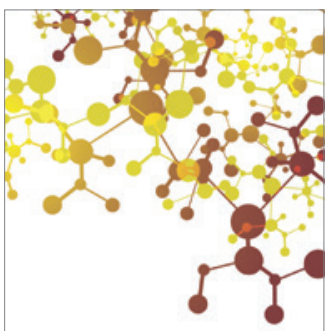

Journal of

Applied Chemistry

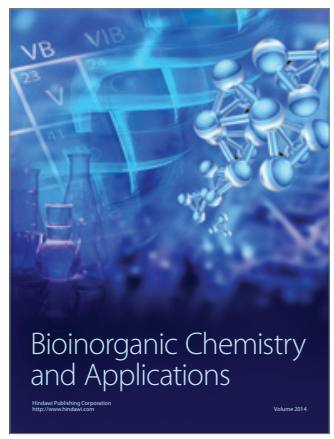

Inorganic Chemistry
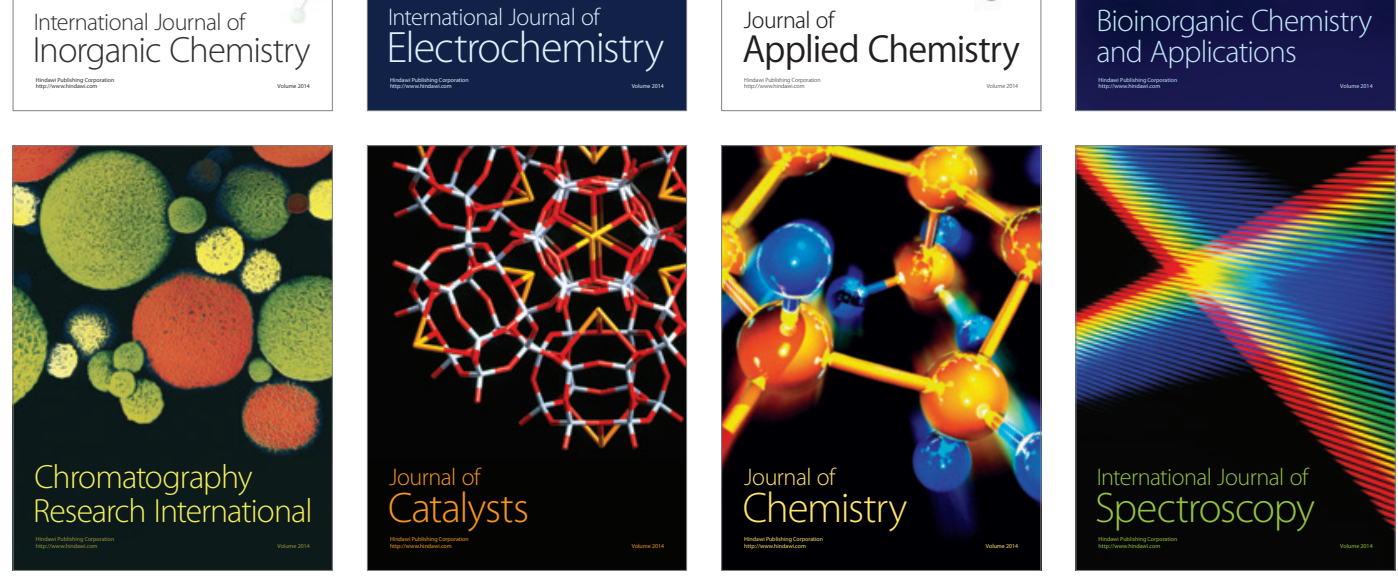